\title{
Edge effects on ground-dwelling beetles (Carabidae and Staphylinidae) in oak forest-forest edge-grassland habitats in Hungary
}

\author{
Béla TÓTHMÉRÉSZ ${ }^{1}$, DÁVID D. NAGY ${ }^{1}$, SZABOLCS MIZSER ${ }^{1}$, DÁVID BOGYÓ² and TiBor MAGURA²
}

\begin{abstract}
${ }^{1}$ MTA-DE Biodiversity and Ecosystem Services Research Group, University of Debrecen, P.O. Box 71, Debrecen H-4010, Hungary; e-mails: tothmerb@gmail.com; david.nagy111@gmail.com; mizserszabolcs@gmail.com

${ }^{2}$ Department of Ecology, University of Debrecen, P.O. Box 71, Debrecen H-4010, Hungary; e-mails: davidbogyo@yahoo.co.uk; maguratibor@gmail.com
\end{abstract}

Key words. Coleoptera, Carabidae, Staphylinidae, edge-associated species, diversity, forest edge, ground beetles, indicator species, rove beetles

\begin{abstract}
Forest edges are essential to the maintenance of biodiversity at the landscape level. According to the edge effect hypothesis, diversity is higher in an edge than in adjacent areas. We tested the edge effect hypothesis for carabids and staphylinids in an oak forestforest edge-grassland complex in the Hajdúság Landscape Protection Area (Hungary). The habitat types were as follows: (1) a closed oak forest with shrubs and herbaceous plants, (2) a forest edge with extensive ground vegetation and shrub cover and (3) grassland with dense herbaceous vegetation. We collected data from 60 pitfall traps ( 2 spatial replicates $\times 3$ habitats $\times 10$ traps). The GLM results showed that the species richness of carabids was higher at the edge of the forest than in the grassland and forest interior; the number of carabid individuals was highest in the grassland. The number of staphylinids and their species richness were significantly lower in the grassland than in the forest edge and interior. The results of principal coordinates analysis showed that the assemblages of both taxa in the forest edge and interior were separated from the assemblage in the grassland area. There were significant characteristic species for the edge habitat, as revealed by the IndVal (indicator species analysis) method. Our findings suggest that forest edges play a vital role in the maintenance of the diversity of carabid and staphylinid assemblages.
\end{abstract}

\section{INTRODUCTION}

Habitat fragmentation and alteration are the major drivers of biodiversity loss in natural habitats (Magura, 2002; Fahrig, 2003; Rösch et al., 2013). These processes modify the structure of landscapes and create complex ecotones and homogenous adjacent habitats (Fahrig, 2003; Ries et al., 2004). For example, the increasing destruction and fragmentation of habitats has led to an increase in forest edges, while forest interiors become smaller in many areas (Magura, 2002). In other areas, the original forest edges have disappeared due to recent plantations or abandonment of farmland (Saunders et al., 1991). These alterations change the abiotic and biotic conditions of the natural habitats, which can influence the composition of assemblages of ground-dwelling invertebrates (Magura et al., 2001).

Forest edges are transitional zones between forest and adjacent open habitats (Matlack, 1993). These zones allow or prevent migration between populations and are unique habitats favoured by certain species and inhospitable to others (Holland et al., 1991). Thus, forest edges have vital effects on adjacent biotas: certain native forest species may decline or go extinct due to the reduction in the interior areas of forests and changes in environmental conditions (light regime, substrates, soil moisture) (Murcia, 1995). In addition, the forest edge can serve as a source habitat or stepping-stone for species from both adjoining habitats (den Boer, 1981; Pulliam, 1988). Moreover, the edge may act as an ecological trap for some insects (Ries \& Fagan, 2003) or a shelter, leading to species that are characteristic to the forest edges, i.e., edge-associated species (Molnár et al., 2001; Horváth et al., 2002; Magura, 2002). These edge-associated species are adapted to forest edges with a distinct structure and/or microclimate and are not present in adjacent habitats, which thereby increases the biodiversity within forest edges (Odum, 1971; Magura et al., 2001).

The effect of forest edges on epigeic arthropods is documented in many previous studies (Molnár et al., 2001; Magura, 2002; Ries \& Sisk, 2008; Antonović et al., 2012). Nonetheless, the majority of these studies have focused on ground beetles or spiders (Magura \& Tóthmérész, 1997; Horváth et al., 2002; Pohl et al., 2007). Other taxa can also respond quickly and distinctly to the effects of environmental and human disturbances. Thus, it is necessary to determine the effect of these influences on other arthropods. In this study, we examined the edge effect on carabid and staphylinid beetles (Coleoptera: Carabidae, Staphylinidae). These species are ecologically important insect components of the soil fauna; they are diverse and abundant taxa and are good indicators of abiotic (physical and chemical) and biotic (interactions among plant and animal species) changes, as well as environmental and human disturbances (Lövei \& Sunderland, 1996; Boháč, 1999; Magura et al., 2013). These properties indicate that these taxa are particularly useful for monitoring changes in diversity and/or in ecological studies (Niemelä et al., 1993; Boháč, 1999; Rainio \& Niemelä, 2003).

In the present study we tested the edge effect hypothesis, which states that species richness is higher in an edge 
between habitats than in the adjoining habitats and/or that there are edge-associated characteristic species (Samways, 1994). We expected that the edge-associated species and species from adjoining habitats cause the increase in species richness in the forest edge. We also studied the distribution of carabid and staphylinid assemblages in a grassland habitat, forest edge and forest interior and identified the characteristic species of each habitat type using IndVal (indicator species analysis) method (Niemelä \& Spence, 1994; Dufrêne \& Legendre, 1997; Magura et al., 2000; Elek et al., 2001).

\section{MATERIAL AND METHODS}

\section{Site description and sampling}

The research area was located in the Hajdúság Landscape Protection Area (Hungary) in a lowland oak forest - grassland complex $\left(47^{\circ} 32^{\prime} 58.27^{\prime \prime} \mathrm{N}\right.$ and $\left.21^{\circ} 56^{\prime} 12.25^{\prime \prime} \mathrm{E}\right)$. We studied three habitat types: (1) forest interior - a closed oak forest with thick litter and an herbaceous and shrub layer and $85-95 \%$ canopy cover; (2) forest edge - a shrubby forest edge with more ground vegetation and a shrub layer; and (3) grassland area - mesophilous grassland with dense herbaceous vegetation.

We collected beetles using pitfall traps (diameter $65 \mathrm{~mm}$ ) containing $100 \mathrm{ml}$ of $70 \%$ ethylene glycol as a killing-preserving solution. The traps were covered with a square $(20 \times 20 \mathrm{~cm})$ of fiberboard for protection from litter and rain (Spence \& Niemelä, 1994). The study sites in the grassland and forest interior were 25 $\mathrm{m}$ from the forest edge, which was $6-14 \mathrm{~m}$ wide. Ten traps were placed in each habitat type. We followed Niemelä et al. (2000), who developed a standardized sampling protocol and proposed that pitfall traps should be installed in a random arrangement at least $10 \mathrm{~m}$ apart to ensure independent sampling. Therefore, traps were placed at least $10 \mathrm{~m}$ apart from each other. There were two spatial replicates of the sampling sites, separated by a distance of more than $100 \mathrm{~m}$. There were thus 60 traps altogether ( 2 spatial replicates $\times 3$ habitat types $\times 10$ traps). The traps were emptied every fourth week from the beginning of May to the end of October 2009, i.e. 6 times. All carabid and staphylinid beetles in the samples were identified to species using standard keys (Lohse, 1974; Hůrka, 1996; Assing \& Schülke, 2011).

\section{Data analyses}

Prior to the analyses, we pooled the catches per trap for the entire year. We used factorial GLMs to test for differences in the number of individuals and the species richness of carabids and staphylinids among the three habitat types (forest interior, forest edge and grassland). We used quasi-Poisson log link function to account for overdispersion in the data (Zuur et al., 2009). When the overall GLMs revealed a significant difference between the means, an LSD test was performed for multiple comparisons among means. Analyses were performed using STATISTICA 8.0. The composition of carabid and staphylinid assemblages at the trap level was displayed using principal coordinates analysis $(\mathrm{PCoA})$ based on a Bray-Curtis index of dissimilarity, which is sensitive to changes in the relative abundances of the species (Pielou, 1984).

We used the IndVal (indicator species analysis) method to explore the characteristic species in the forest, forest edge, and grassland habitats (Dufrêne \& Legendre, 1997). The indicator value (IndVal) of a species is expressed as a product of the specificity and fidelity measure. The specificity measure $\left(A_{i j}\right)$ is defined as follows:

$$
A_{i j}=\frac{N_{i j}}{N_{i .}}
$$

where $N_{i j}$ is the mean number of individuals of species $i$ across sites of group $j$, whereas $N_{i}$ is the sum of the mean numbers of individuals of species $i$ across all groups. The fidelity of the species is measured by $B_{i j}$ :

$$
B_{i j}=\frac{S_{i j}}{S_{. j}}
$$

where $S_{i j}$ is the number of sites in cluster $j$ at which species $i$ is present, whereas $S_{. j}$ is the total number of sites in that cluster. Therefore, the Indicator Value (IndVal $)$ is as follows:

$$
\text { IndVal }_{i j}=A_{i j} \times B_{i j} \times 100 .
$$

The indicator value of species $i$ is the largest value of IndVal $l_{i j}$ recorded over all site groups $j$. The indicator value is at a maximum (100) when all individuals of a species are found in a single group of sites (high specificity) and when the species occurs in all sites of that group (high fidelity). The IndVal method uses a Monte Carlo permutation test to estimate the statistical significance of the species indicator value, i.e., a random reallocation procedure of sites among site groups is used during the estimation of the significance of a characteristic species. The significance is evaluated by the difference between the observed value and the mean of those obtained from random permutations (999 permutations were used) (Dufrêne \& Legendre, 1997).

De Cáceres et al. (2010) suggest that all possible combinations of groups of sites should be considered during the indicator species analysis (IndVal method). Therefore, we considered all spatially meaningful combinations of habitats in the analysis. We used the IndVal 2.0 package (Dufrêne \& Legendre, 1997).

\section{RESULTS}

We collected 57 carabid species (3006 individuals) and 87 staphylinid species (1458 individuals). Staphylinus caesareus (11.2\% of staphylinids) and Carabus cancellatus (21\% of carabids) were the most frequent species overall and in the grassland habitat. At the edge, Omalium caesum (staphylinid) and Platyderus rufus (carabid) were the most numerous, whereas Oxypoda acuminata (staphylinid) and Pterostichus niger (carabid) were the most numerous in the forest interior (Table 1).

The GLMs revealed significant differences in the number of individuals and species richness among the habitats. Total number of carabid individuals was significantly higher in the grassland than in the edge and forest interior $\left(\chi^{2}=150.0 ; \mathrm{df}=2 ; \mathrm{p}<0.0001\right.$, Fig. 1a). Species richness of carabids was significantly higher in the edge than in the grassland and forest interior $\left(\chi^{2}=21.4\right.$; $\mathrm{df}=2 ; \mathrm{p}<0.0001$, Fig. 1b). Total number of staphylinid individuals was significantly lower in the grassland than in the edge and forest interior $\left(\chi^{2}=25.0 ; \mathrm{df}=2 ; \mathrm{p}<0.0001\right.$, Fig. 2a). The overall species richness of staphylinids was highest in the edge habitat; the lowest species number was recorded in the grassland ( $\chi^{2}=62.1 ; \mathrm{df}=2 ; \mathrm{p}<0.0001$, Fig. $2 b$ ).

The composition of both carabid and staphylinid assemblages changed slightly from the forest interior to the edge and then drastically in the grassland (Fig. 3a, b). PCoA ordination for both taxa revealed that the grassland assemblage separated from the forest interior and edge assem- 
TABLE 1. Indicator power of the carabid and staphylinid species that are significantly $(p<0.05)$ characteristic of the three habitats. The IndVal column shows the species indicator value for the corresponding clustering level. Grassland, Edge and Forest columns: numbers given are the number of specimens trapped / number of traps in which the species was present.

\begin{tabular}{|c|c|c|c|c|}
\hline & IndVal & Grassland & Edge & Forest \\
\hline \multicolumn{5}{|l|}{$\overline{\text { CARABIDAE }}$} \\
\hline \multicolumn{5}{|l|}{ Forest } \\
\hline Pterostichus niger & 73.69 & $9 / 3$ & $24 / 13$ & $215 / 17$ \\
\hline Pterostichus oblongopunctatus & 44.05 & $0 / 0$ & $5 / 4$ & $37 / 10$ \\
\hline \multicolumn{5}{|l|}{ Forest and edge } \\
\hline Platyderus rufus & 85.84 & $4 / 4$ & $116 / 19$ & $49 / 17$ \\
\hline Badister lacertosus & 52.50 & $0 / 0$ & $22 / 12$ & $13 / 9$ \\
\hline Pterostichus strenuus & 47.50 & $0 / 0$ & $14 / 8$ & $25 / 11$ \\
\hline Oxypselaphus obscurus & 40.00 & $0 / 0$ & $25 / 10$ & $8 / 6$ \\
\hline Stomis pumicatus & 40.00 & $0 / 0$ & $5 / 5$ & $13 / 11$ \\
\hline Harpalus tardus & 38.18 & $1 / 1$ & $29 / 10$ & $13 / 6$ \\
\hline Dyschirius globosus & 35.61 & $3 / 3$ & $22 / 10$ & $9 / 7$ \\
\hline Bembidion guttula & 22.50 & $0 / 0$ & $8 / 5$ & $14 / 4$ \\
\hline \multicolumn{5}{|l|}{ Edge } \\
\hline Amara convexior & 68.99 & $5 / 3$ & $56 / 17$ & $8 / 7$ \\
\hline Leistus ferrugineus & 35.00 & $0 / 0$ & $8 / 7$ & $0 / 0$ \\
\hline Badister bullatus & 21.54 & $2 / 2$ & $8 / 7$ & $3 / 3$ \\
\hline Amara anthobia & 20.00 & $0 / 0$ & $5 / 4$ & $0 / 0$ \\
\hline \multicolumn{5}{|l|}{ Grassland } \\
\hline Carabus cancellatus & 89.80 & $515 / 20$ & $97 / 18$ & $20 / 10$ \\
\hline Calathus fuscipes & 89.54 & $390 / 18$ & $0 / 0$ & $4 / 1$ \\
\hline Pterostichus melas & 87.76 & $398 / 20$ & $59 / 14$ & $52 / 9$ \\
\hline Pterostichus melanarius & 79.42 & $275 / 16$ & $3 / 2$ & $1 / 1$ \\
\hline Poecilus versicolor & 67.50 & $27 / 14$ & $0 / 0$ & $2 / 1$ \\
\hline Poecilus cupreus & 65.00 & $129 / 13$ & $0 / 0$ & $0 / 0$ \\
\hline Bembidion properans & 60.00 & $29 / 12$ & $0 / 0$ & $0 / 0$ \\
\hline Harpalus rubripes & 14.12 & $8 / 3$ & $1 / 1$ & $0 / 0$ \\
\hline \multicolumn{5}{|l|}{ STAPHYLINIDAE } \\
\hline \multicolumn{5}{|l|}{ Forest } \\
\hline Oxypoda acuminata & 77.48 & $3 / 3$ & $13 / 7$ & $99 / 18$ \\
\hline Othius punctulatus & 47.50 & $0 / 0$ & $3 / 2$ & $19 / 11$ \\
\hline Sepedophilus marshami & 30.59 & $0 / 0$ & $4 / 4$ & $13 / 8$ \\
\hline \multicolumn{5}{|l|}{ Forest and edge } \\
\hline Xantholinus tricolor & 88.36 & $5 / 4$ & $47 / 18$ & $86 / 20$ \\
\hline Omalium caesum & 75.92 & $4 / 3$ & $89 / 16$ & $60 / 16$ \\
\hline Gabrius osseticus & 65.00 & $2 / 2$ & $31 / 14$ & $21 / 14$ \\
\hline Anthobium atrocephalum & 63.09 & $1 / 1$ & $29 / 12$ & $37 / 14$ \\
\hline Omalium rivulare & 60.00 & $0 / 0$ & $25 / 10$ & $51 / 14$ \\
\hline Ilyobates nigricollis & 59.95 & $1 / 1$ & $25 / 12$ & $22 / 13$ \\
\hline Rugilus rufipes & 58.14 & $3 / 1$ & $25 / 11$ & $55 / 14$ \\
\hline Quedius curtipennis & 45.00 & $0 / 0$ & $9 / 8$ & $11 / 10$ \\
\hline Liogluta longiuscula & 40.20 & $1 / 1$ & $17 / 8$ & $18 / 9$ \\
\hline Lathrobium geminum & 39.46 & $1 / 1$ & $8 / 6$ & $18 / 11$ \\
\hline Oxypoda abdominalis & 30.00 & $0 / 0$ & $7 / 5$ & $14 / 7$ \\
\hline Tasgius morsitans & 22.50 & $0 / 0$ & $10 / 5$ & $4 / 4$ \\
\hline \multicolumn{5}{|l|}{ Edge } \\
\hline Tasgius winkleri & 43.75 & $1 / 1$ & $14 / 10$ & $1 / 1$ \\
\hline Falagrioma thoracica & 42.65 & $0 / 0$ & $29 / 10$ & $5 / 4$ \\
\hline Tasgius melanarius & 38.70 & $3 / 3$ & $19 / 11$ & $5 / 3$ \\
\hline Olophrum assimile & 37.65 & $1 / 1$ & $16 / 8$ & $0 / 0$ \\
\hline Platydracus fulvipes & 33.75 & $0 / 0$ & $12 / 9$ & $4 / 4$ \\
\hline Pella limbatus & 30.00 & $0 / 0$ & $17 / 6$ & $0 / 0$ \\
\hline Ouedius limbatus & 20.00 & $0 / 0$ & $5 / 4$ & $0 / 0$ \\
\hline Oxypoda longipes & 19.44 & $0 / 0$ & $7 / 5$ & $2 / 2$ \\
\hline \multicolumn{5}{|l|}{$\begin{array}{l}\text { Grassland } \\
\text { Gents }\end{array}$} \\
\hline Staphylinus caesareus & 94.71 & $163 / 19$ & $0 / 0$ & $1 / 1$ \\
\hline Tasgius pedator & 47.37 & $18 / 10$ & $2 / 2$ & $0 / 0$ \\
\hline Drusilla canaliculata & 41.62 & $28 / 11$ & $15 / 8$ & $3 / 2$ \\
\hline Dinaraea angustula & 25.00 & $7 / 5$ & $0 / 0$ & $0 / 0$ \\
\hline Ouedius molochinus & 24.50 & $7 / 7$ & $6 / 5$ & $0 / 0$ \\
\hline Philonthus concinnus & 20.00 & $4 / 4$ & $0 / 0$ & $0 / 0$ \\
\hline Falagria sulcatula & 16.67 & $5 / 4$ & $2 / 2$ & $0 / 0$ \\
\hline Philonthus corruscus & 15.00 & $3 / 3$ & $0 / 0$ & $0 / 0$ \\
\hline
\end{tabular}

blages along the first axis. The carabid assemblages of the forest interior and the forest edge were separated along the second axis. Thus, the compositions of the assemblages in the forest interior and edge were more similar to each other than to that in the grassland.

Five groups of characteristic species were identified by the IndVal method: (1) habitat generalists that were pre- sent in all habitats; (2) forest specialists that were found mostly in the forest interior (two significant characteristic species of carabids and three of staphylinids); (3) forest generalists that occurred exclusively or mostly in the forest interior and forest edge and were not present or rare in the grassland habitat (eight significant characteristic species of carabids and 12 of staphylinids); (4) edge-associated 

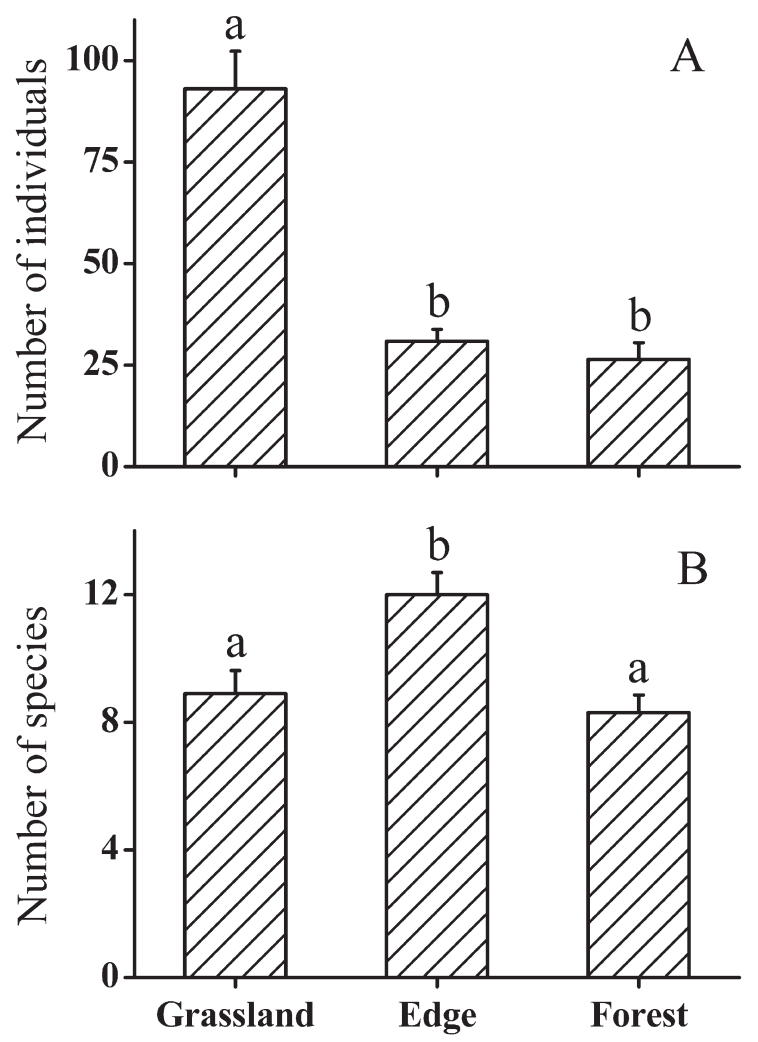

Fig. 1. Mean $( \pm \mathrm{SE})$ number of individuals $(A)$ and species richness (B) of carabids per trap recorded in each habitat. Means with different letters indicate a significant $(p<0.05)$ difference.

species that were recorded exclusively in the edge or were common in the edge and sparse or missing in the adjacent habitats (four significant characteristic species of carabids and eight of staphylinids); and (5) grassland-associated species that were found exclusively or in high numbers in the grassland (eight significant characteristic species of carabids and eight of staphylinids, Table 1).

\section{DISCUSSION}

Several previous studies demonstrated an edge effect in the distribution of carabids (Magura \& Tóthmérész, 1998; Elek \& Tóthmérész, 2010). However, only few studies have investigated this effect in staphylinids (Golden \& Crist, 2000; Pohl et al., 2007, 2008). Pohl et al. (2007) show that the species richness is slightly higher in an open habitat than in a forest and there are no other clear trends. A forest area within at least $10 \mathrm{~m}$ of the edge may be colonized by open habitat species but is not a suitable habitat for all the forest species (Pohl et al., 2008). Thus, the staphylinid assemblage in the forest edge is more closely related to the open habitat assemblage than the deep forest assemblage (Pohl et al., 2007). Our results support the edge effect hypothesis in carabids because the species richness of carabids was significantly higher in the forest edge than in the grassland and forest interior. In contrast to Pohl et al. (2007), we found that the staphylinid assemblage in the edge was more similar to the forest assemblage than to the grassland assemblage. Similar to our results, several studies also show that the carabid assemblage in the edge is
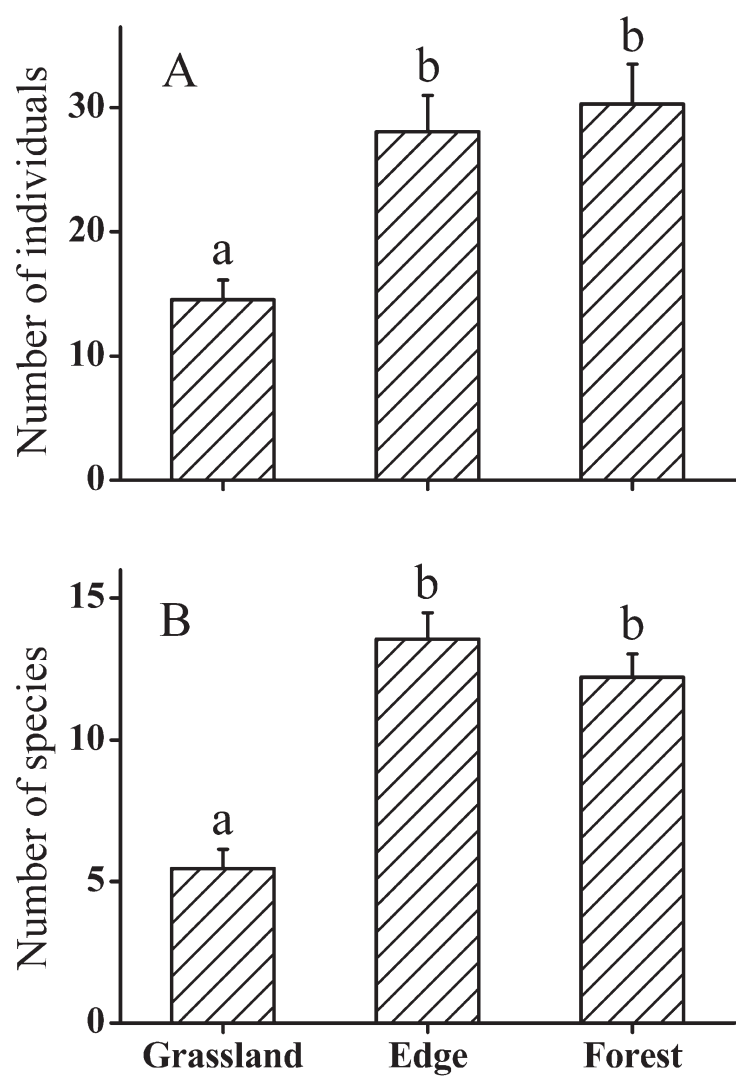

Fig. 2. Mean $( \pm$ SE) number of individuals $(A)$ and species richness (B) of staphylinids per trap recorded in each habitat. Means with different letters indicate a significant $(p<0.05)$ difference.

similar to the assemblage in the forest interior (Magura et al., 2001; Molnár et al., 2001).

The ordination and the IndVal method demonstrated that distinct species assemblages occurred in each of the three habitats (Fig. 3 and Table 1). Similar to our results, Koch (1989) and Stan (2008) report that the carabid species Pterostichus niger and Pterostichus oblongopunctatus and staphylinid species Oxypoda acuminata and Othius punctulatus are forest specialists. Magura et al. (2000, 2001) show that Pterostichus niger prefers a forest edge, whereas Pterostichus oblongopunctatus is present in both forest interiors and forest edges. Several edge-associated species (e.g., Amara convexior, Tasgius winkleri, Falagrioma thoracica and Tasgius melanarius) were present in both the grassland and/or forest areas. Previous studies also show that these species occur in all three habitats (Koch, 1989; Hůrka, 1996) but may disperse to adjacent habitats during the period when they are active. Magura et al. (2001) also report seasonal dispersal between adjacent habitats associated with annual changes in habitat structure and environmental conditions. Moreover, our results support the findings of Koch (1989) that the staphylinid species Staphylinus caesareus, Tasgius pedator, Philonthus concinnus and Philonthus corruscus prefer open habitats. Similar to our findings Magura et al. $(2000,2001)$ also report that the carabids Calathus fuscipes, Pterostichus melanarius and Poecilus cupreus are significant characteristic species of grassland. 

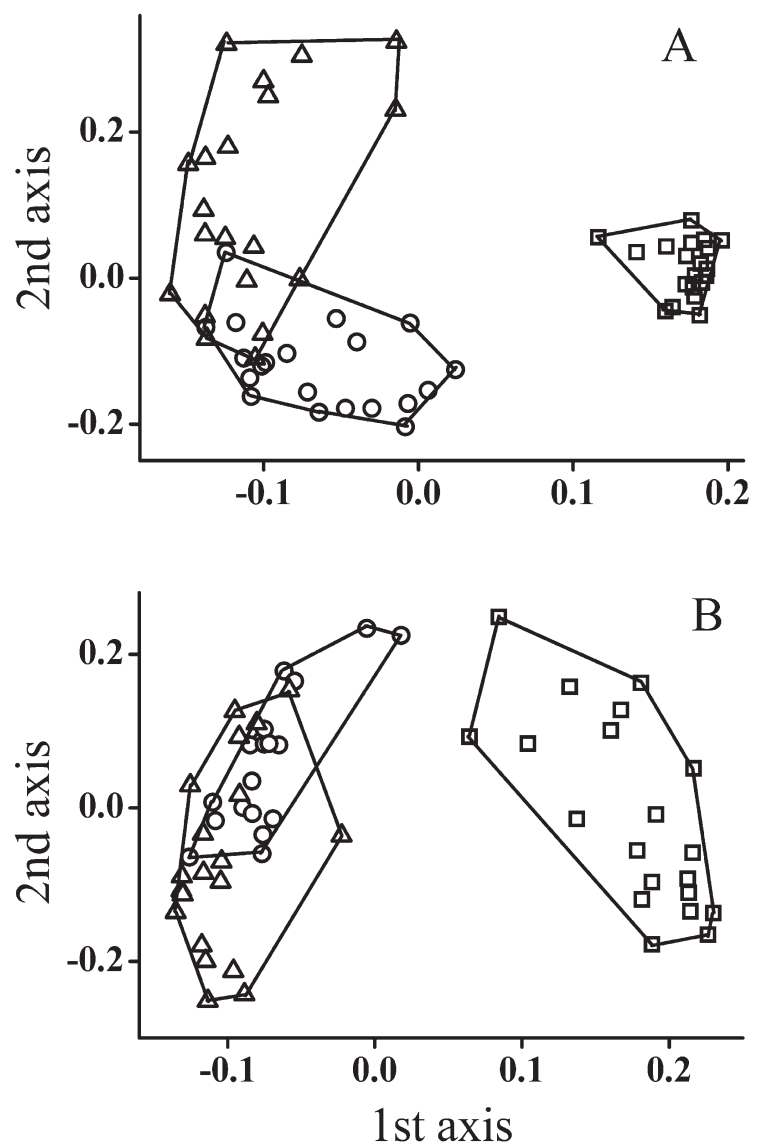

Fig. 3. Ordination of the pitfall trap catches of carabids (A) and staphylinids (B). Principal coordinate analysis ( $\mathrm{PCoA}$ ) with a Bray-Curtis dissimilarity was used to assess similarities in carabid and staphylinid assemblages among the traps. Notations: empty squares - grassland traps; empty circles - edge traps; and empty triangles - forest traps.

Niemelä (1988) reports that small-scale dispersal between habitat patches influences the composition and structure of carabid assemblages. Thus, dispersal may result in an increase in the diversity in the edge as ground-dwelling beetles may cover long distances searching for food and/ or habitats (reproduction and hibernation) and exhibit density-dependent migration and aggregation in habitats where prey is abundant (Magura et al., 2001). Pterostichus niger and Pterostichus oblongopunctatus were significant characteristic species of the forest interior (Table 1). However, they were also recorded in the forest edge. Several open-habitat species apparently migrated into the forest edge from the surrounding grassland (Carabus cancellatus, Pterostichus melas). A similar pattern was recorded for staphylinids: certain characteristic species of the adjacent habitats were also present in the forest edge $(O x$ ypoda acuminata, Othius punctulatus, Tasgius pedator and Drusilla canaliculata) (Table 1). It is known that changes in habitat structure and microclimate enable open-habitat species of both families to colonize forest edges (Murcia, 1995; Spence et al., 1996; Pohl et al., 2007). Spence et al. (1996) also show that forest specialist species have an important role in maintaining carabid populations in forest edges by recolonization. Pohl et al. (2007) show that edges may not be suitable habitats for forest specialist staphylinid species. We found that three characteristic staphylinid species of the forest interior (Oxypoda acuminata, Othius punctulatus and Sepedophilus marshami) were also present in the forest edge.

The edge-associated species (Amara convexior, Leistus ferrugineus, Tasgius winkleri and Falagrioma thoracica) and immigration of species from other habitats contributed to the increased diversity of ground-dwelling beetles in the forest edge. Thus, the species characteristic of adjacent habitats (forest and grassland) and those inhabiting the edge resulted in higher diversity in the forest edge. There was no significant difference in the species richness of staphylinids in the forest interior and edge. However, based on the results of the IndVal analysis, several species were significantly associated with the forest edge, which indicates an edge effect.

Natural and human disturbances (burning, grazing, and mowing) affect natural habitats (Odum, 1971). These processes can change the abiotic and biotic environmental conditions, which may in turn influence arthropod assemblages communities. Even if adjacent habitats are altered, forest edges can still provide food resources and protection for carabid and staphylinid species that are characteristic of grassland and forest interior habitats (Magura et al., 2001). Thus, forest edges support viable populations from adjacent habitats and can serve as a source habitat or stepping-stone for dispersal (den Boer, 1981; Pulliam, 1988). Furthermore, after the restoration of degraded habitats, forest edges can contribute to the recolonization by carabid and staphylinid species. A high diversity of plants and ground-dwelling beetles can be maintained and encouraged by suitable management practices and controlled habitat treatments (Anderson \& Carter, 1987; Ingham \& Samways, 1996; Golden \& Crist, 2000; Magura et al., 2001). Our results suggest that forest edges may play a vital role in the maintenance and preservation of the diversity of carabids and staphylinids. Thus, poorly developed forest edges (e.g., plantations and managed forests) should be augmented by sowing or planting herbaceous plants and shrubs (Magura et al., 2001).

ACKNOWLEDGEMENTS. We are grateful to R. Horváth, L. Lality, G. Szabó and O. Szalkovszki for their help with fieldwork. We are also grateful to G. Makranczy and L. Ádám for their help in species identification. This work was partially supported by the European Union and the European Social Fund through projects no. TÁMOP 4.2.1./B-09/1/KONV-2010-0007 and TÁMOP4.2.2/B-10/1-2010-0024 and co-financed by the European Social Fund in the framework of TÁMOP 4.2.4. A/2-11-1-2012-0001 "National Excellence Program".

\section{REFERENCES}

ANDERSON M.A. \& CARTER C.I. 1987: Shaping ride sides to benefit wild plants and butterflies. In Jardine D.C. (ed.): Wildlife Management in Forests. Institute of Chatered Forests, Lancaster, pp. 66-88.

Antonović I., Brigić A., Sedlar Z., Bedek J. \& Šoštarić R. 2012: Terrestrial isopod community as indicator of succession in a peat bog. - Zookeys 176: 171-188. 
Assing V. \& SchüLKe M. 2011: Freude-Harde-Lohse-Klausnitzer - Die Käfer Mitteleuropas. Band 4. Staphylinidae I. Zweite neubearbeitete Auflage. Spektrum, Heidelberg, Berlin, 560 pp.

ВонÁČ J. 1999: Staphylinid beetles as bioindicators. - Agr. Ecosyst. Environ. 74: 357-372.

DEN BOER P.J. 1981: On the survival of populations in a heterogeneous and variable environment. - Oecologia 50: 39-53.

De Cáceres M., Legendre P. \& Moretti M. 2010: Improving indicator species analysis by combining groups of sites. - Oikos 119: $1674-1684$.

DufrêNe M. \& Legendre P. 1997: Species assemblages and indicator species: The need for a flexible asymmetrical approach. - Ecol. Monogr. 67: 345-366.

Elek Z., Magura T. \& Tóthmérész B. 2001: Impacts of non-native Norway spruce plantation on abundance and species richness of ground beetles (Coleoptera: Carabidae). - Web. Ecol. 2: 32-37.

EleK Z. \& TóthMÉRÉsz B. 2010: Carabid beetles among grassland-forest edge-beech forest habitats in Northern Hungary. Comm. Ecol. 11: 211-216.

FAHRIG L. 2003: Effects of habitat fragmentation on biodiversity. - Annu. Rev. Ecol. Evol. Syst. 34: 487-515.

Golden D.M. \& CRIST T.O. 2000: Experimental effects of habitat fragmentation on rove beetles and ants: patch area or edge? Oikos 90: 525-538.

Holland M.M., Risser P.G. \& Naiman R.J. 1991: Ecotones. The Role of Landscape Boundaries in the Management and Restoration of Changing Environments. Chapman and Hall, London, $142 \mathrm{pp}$.

Horváth R., Magura T., Péter G. \& Tóthmérész B. 2002: Edge effect on weevil and spiders. - Web. Ecol. 3: 43-47.

HưRKA K. 1996: Carabidae of the Czech and Slovak Republics Karbourek, Zlín, 565 pp.

Ingham D.S. \& SAmwaYs M.J. 1996: Application of fragmentation and variegation models to epigaeic invertebrates in South Africa. - Conserv. Biol. 10: 1353-1358.

Косн K. 1989: Die Käfer Mitteleuropas. Ökologie. Band 1. Goecke \& Evers, Krefels, 440 pp.

LoHse G.A. 1974: Staphylinidae II (Hypocyphtinae und Aleocharinae) Pselaphidae, Bd. 5. In Freude V.H., Harde K.W. \& Lohse G.A. (eds): Die Käfer Mitteleuropas. Goecke \& Evers, Krefeld, $304 \mathrm{pp}$

LÖVEI G.L. \& SundeRLAND K.D. 1996: Ecology and behavior of ground beetles (Coleoptera: Carabidae). - Annu. Rev. Entomol. 41: 231-256.

Magura T. 2002: Carabids and forest edge: spatial pattern and edge effect. - Forest Ecol. Manag. 157: 23-37.

Magura T. \& Tóthmérész B. 1997: Testing edge effect on carabid assemblages in an oak-hornbeam forest. - Acta Zool. Acad. Sci. Hung. 43: 303-312.

Magura T. \& TóthMÉrész B. 1998: Edge effect on carabids in an oak-hornbeam forest at the Aggtelek National Park (Hungary) - Acta Phytopath. Entomol. Hung. 33: 379-387.

Magura T., Tóthmérész B. \& Molnár T. 2000: Spatial distribution of carabids along grass-forest transects. - Acta Zool. Acad. Sci. Hung. 46: 1-17.

MAgura T., TóthMÉrész B. \& MolnÁr T. 2001: Forest edge and diversity: carabids along forest-grassland transects. - Biodiv Conserv. 10: 287-300.

Magura T., Nagy D. \& Tóthmérész B. 2013: Rove beetles respond heterogeneously to urbanization. - J. Insect Conserv. 17: 715-724.

MatLaCK G.R. 1993: Microenvironment variation within and among forest edge sites in the eastern United-States. - Biol. Conserv. 66: 185-194.
MolnÁr T., Magura T., Tóthmérész B. \& Elek Z. 2001: Ground beetles (Carabidae) and edge effect in oak-hornbeam forest and grassland transects. - Eur. J. Soil. Biol. 37: 297-300.

MuRCIA C. 1995: Edge effects in fragmented forests - implications for conservation. - Trends Ecol. Evol. 10: 58-62.

NIEMELÄ J. 1988: Carabid beetles in shore habitats on the Åland Islands, SW Finland: the effect of habitat availability and species characteristics. - Acta Ecol./Ecol. Gener. 9: 379-395.

NIEMELÄ J.K. \& SPENCE J.R. 1994: Distribution of forest dwelling carabids (Coleoptera) - spatial scale and the concept of communities. - Ecography 17: 166-175.

Niemelä J., LANGor D. \& SPence J.R. 1993: Effects of clear-cut harvesting on boreal ground-beetle assemblages (Coleoptera: Carabidae) in western Canada. - Conserv. Biol. 7: 551-561.

Niemelä J., Kotze J., Ashworth A., Brandmayr P., Desender K., New T., Penev L., Samways M. \& Spence J. 2000: The search for common anthropogenic impacts on biodiversity: a global network. - J. Insect Conserv. 4: 3-9.

Odum E.P. 1971: Fundamentals of Ecology. Saunders, Philadelphia, 574 pp.

Pielou E.C. 1984: The Interpretation of Ecological Data: A Primer on Classification and Ordination. Wiley, New York, 288 pp.

Pohl G.R., Langor D.W. \& Spence J.R. 2007: Rove beetles and ground beetles (Coleoptera: Staphylinidae, Carabidae) as indicators of harvest and regeneration practices in western Canadian foothills forests. - Biol. Conserv. 137: 294-307.

Pohl G., Langor D.W., Klimaszewski J., Work T. \& Paquin P. 2008: Rove beetles (Coleoptera: Staphylinidae) in northern Nearctic forests. - Can. Entomol. 140: 415-436.

Puldiam H.R. 1988: Sources, sinks, and population regulation. Am. Nat. 132: 652-661.

RaInIo J. \& Niemelä J. 2003: Ground beetles (Coleoptera: Carabidae) as bioindicators. - Biodiv. Conserv. 12: 487-506.

RIES L. \& FAGAN W.F. 2003: Habitat edges as a potential ecological trap for an insect predator. - Ecol. Entomol. 28: 567-572.

Ries L. \& Sisk T.D. 2008: Butterfly edge effects are predicted by a simple model in a complex landscape. - Oecologia 156: 75-86.

Ries L., Fletcher R.J., Battin J. \& Sisk T.D. 2004: Ecological responses to habitat edges: Mechanisms, models, and variability explained. - Annu. Rev. Ecol. Evol. Syst. 35: 491-522.

Rösch V., Tscharntke T., Scherber C. \& Batáry P. 2013: Landscape composition, connectivity and fragment size drive effects of grassland fragmentation on insect communities. $-J$. Appl. Ecol. 50: 387-394.

Samways M.J. 1994: Insect Conservation Biology. Chapman \& Hall, London, New York, 358 pp.

Saunders D.A., Hobbs R.J. \& Margules C.R. 1991: Biological consequences of ecosystem fragmentation - a review. - Conserv. Biol. 5: 18-32.

SPENCE J.R. \& NIEMELÄ J.K. 1994: Sampling carabid assemblages with pitfall traps - the madness and the method. - Can. Entomol. 126: 881-894.

Spence J.R., Langor D.W., Niemela J., Carcamo H.A. \& CuRRIE C.R. 1996: Northern forestry and carabids: The case for concern about old-growth species. - Ann. Zool. Fenn. 33: 173-184.

STAN M. 2008: New data on the rove beetle fauna (Coleoptera: Staphylinidae) from Bucareşti and its surroundings. - Trav. Mus. Natn. Hist. Natl. 51: 369-386.

Zuur A., Ieno E.N., Walker N., Saveiliev A.A. \& Smith G.M. 2009: Mixed Effects Models and Extensions in Ecology with R. Springer, New York, 574 pp.

Received December 31, 2013; revised and accepted October 28, 2014 Prepublished online November 7, 2014 